\title{
THE LEAKAGE OF SEWER SYSTEMS AND THE IMPACT ON THE 'BLACK AND ODOROUS WATER BODIES' AND WWTPS IN CHINA
}

Cao Y.S. ${ }^{1}$, Tang J.G. ${ }^{2}$, Henze M. ${ }^{3}$, Yang X.P. ${ }^{4}$, Gan Y.P. ${ }^{4}$, Li J. ${ }^{5}$, Krosis H. ${ }^{6}$, van Loosdrecht M.C. M. ${ }^{7}$, Zhang $\mathrm{Y}^{8}{ }^{8}$, Daigger G. T. ${ }^{9}$

${ }^{1} 41$ Tian Jia Xian, Blk 6, 215006 Suzhou, China (communication author: cao_yeshi1949@hotmail.com).

2 Shanghai Urban Construction, Design and Research Institute, No 3447 Dong Fang Rd., 200125 Shanghai, China (13061702548@163.com)

${ }^{3}$ Department of Environ. Eng., Technical University of Denmark Bldg., 115 DK-2860, Lyngby, Denmark (moh@env.dtu.dk)

${ }^{4}$ China Water and Wastewater Treatment Association, No. 5 East road Lian Huwa Est Rd, B Tower Time Square 2310, Beijing (13801090427@163.com; gyp@bdc.cn)

${ }^{5}$ School of Environ \& Civil Eng., Jia Nang University. No 1800 Li Avenue, Pin Hou District, Wuxi, China (lji18@126.com)

${ }^{6}$ Institute of Water Quality and Resource Management. Vienna University of Technology, Vienna 1040 Austria (hkroiss@iwaq.tuwien.ac.at)

${ }^{7}$ Department of Biotechnology, Delft University of Technology, Van der Maasweg 9, 2629 HZ Delft, The Netherlands (m.c.m.vanloosdrecht@tudelft.nl)

${ }^{8}$ China Water Industry Association. No. 9, San Li He, 100835 Beijing, China (13911267868@163.com)

${ }^{9}$ Department of Civil and Environ. Eng., University of Michigan, 1351 Beal Avenue, Ann Arbor, MI 48109, USA (gdaigger@umich.edu)

Keywords: Sewer, infiltration, exfiltration, black and odorous water bodies, nutrient removal, municipal wastewater treatment.

ABSTRACT China has achieved significant progress on wastewater treatment and aquatic environmental protection. However, leakage (in- and exfiltration) of sewer systems is still an issue. By using the statistical data of water and wastewater in 2016 in China, and the Person Loads (PLs) of water and wastewater in Singapore the leakage fractions of hydraulic flow, organic carbon (COD), nitrogen (N) and phosphorus (P) mass loading, and in-sewer COD biological removal in the sewer systems of China (except Hong Kong, Macau and Taiwan), Shanghai, Guangzhou and Beijing were for the first time reported. The fractions of hydraulic flow infiltration (13\%, Shanghai and Guangzhou) and exfiltration (39\%, China) were calculated. Except Beijing, whose sewer networks are under appropriate management with small leakage fractions, the exfiltration fractions of COD (including in-sewer biological COD removal) ranged from $41 \%$ (Shanghai) to $66 \%$ (China) and averaged $55 \%$; for $\mathrm{N}$ ranged from $18 \%$ (Shanghai) to 48\% (China) averaged 33\%; and for $\mathrm{P}$ ranged from 23\% (Shanghai and Guangzhou) to $44 \%$ (China) averaged $30 \%$. The exfiltrated sewage, COD, N and $\mathrm{P}$ not only wastes resources, but also contaminates the aquatic environment (especially groundwater) and contributes to 'black and odorous water bodies'. In- and exfiltration in the sewer network leads to low influent COD concentration, $\mathrm{C} / \mathrm{N}$ ratio and high inorganic solids and inert particulate COD concentrations of many municipal WWTPS

CIWA Publishing [2020]. The definitive peer-reviewed and edited version of this article is published in Water Science \& Technology, Volume 79, Issue 2, 334-341, 2019, doi: 10.2166/wst.2019.051 and is available at www.iwapublishing.com. This is the accepted version. 
causing high cost for nutrient removal, poor resource recovery, additional reactor/settler volume requirement and other operational problems. Therefore, tackling sewer leakage is of primarily importance to today's environment in China. Recommendations for the inspection of sewer systems and the rehabilitation of damaged sewers as well as the development of design and operation guidelines of municipal WWTPs tailored to the specific local sewage characteristics and other conditions are proposed.

\section{INTRODUCTION}

China has achieved significant progress on water pollution control: the total wastewater treatment capacity reached 1,760 million $\mathrm{m}^{3}$ /day in $2016\left({ }^{1} \mathrm{CUWA}, 2017\right)$, the largest in the world $\left({ }^{1} \mathrm{CUWA}, 2017\right)$. However, 'black and odorous water bodies' are still a challenge. The discharge standards for nitrogen and phosphorus have been tightened and implemented national wide (Zheng, 2017). But many municipal wastewater treatment plants (WWTPs) are confronting a series of issues including a needed response to these new discharge regulations.

The influent organic carbon (chemical oxygen demand, COD) concentration is often abnormally low (Table 1) (MHUR, 2017). The average influent COD of municipal WWTPs in China in 2016 was $267 \mathrm{mg}$ COD/I only ( $\left.{ }^{1} \mathrm{CUWA}, 2017\right)$, much lower than 400 up to $1000 \mathrm{mg} \mathrm{COD} / \mathrm{L}$ in Central Europe, and $400 \mathrm{mg} / \mathrm{L}$ on average for whole Europe (Dohmann, 2017). Among 30 provinces and Internal autonomy regions in China there were eight with influent COD $<200 \mathrm{mg} / \mathrm{L}$ on average, and fifteen $<250 \mathrm{mg}$ COD/L ( ${ }^{1} \mathrm{Tang}$, 2017 ). The influent COD of WWTPs with a capacity $\geqslant 100,000 \mathrm{~m}^{3} / \mathrm{d}$ in Guangzhou averaged $181 \mathrm{mg}$ COD/L only (Table 1) (MHUR, 2017). The influent COD of some WWTPs in Southern China is even lower than $\left.100 \mathrm{mg} \mathrm{COD/L} \mathrm{(}{ }^{1} \mathrm{CUWA}, 2017\right)$. The reported influent $\mathrm{C} / \mathrm{N}$ ratio $(7.5-8.8)$ (Table 5$)$ is between the low and typical range (Henze et al., 2002), with high inert particulate COD and low XCOD/SS (defined below) ratio (Dai, 2017; Zheng, 2017; Wu, 2017; Yang, 2017). To direct more carbon for nutrient removal, primary settling tanks (PSTs) were omitted in many municipal WWTPs and only a few anaerobic digesters for energy recovery are in use («10\% of treatment plants) (Dai, 2017) in China. Even so, the addition of carbon is still widely practiced in many WWTPs in China in order to meet nutrient discharge standard (e.g. TN $<10 \mathrm{mg} / \mathrm{L}$, first grade A class discharge standards) (Zheng, 2017). These factors all lead to the unsustainable management and operation of many municipal WWTPs.

The low influent COD concentration of municipal WWTPs indicates leakage (in- and exfiltration) of sewage to/from the sewer systems. Leakage herewith includes in- and out-flow through manholes or broken pipes and water seeping in and out of sewers depending on the relative difference between sewage level in the sewer and the ground/river water level. Infiltration (from external to inside sewer system) happens when the ground/river water level is higher than that in sewer. Exfiltration (from inside sewer to external) happens when ground/river water level is lower than that in sewer. Also a very high drinking water consumption caused by failures of household water infrastructure (valves do not stop water flow any more etc.) or water loss from the water supply network can contribute to low influent concentrations. Adequate modern household infrastructure in Europe results in a water consumption of 100 to 150 L/cap.day. Differing from nitrogen $(\mathrm{N})$ and phosphorus $(\mathrm{P})$ in sewage, biological COD

CIWA Publishing [2020]. The definitive peer-reviewed and edited version of this article is published in Water Science \& Technology, Volume 79, Issue 2, 334-341, 2019, doi: 10.2166/wst.2019.051 and is available at www.iwapublishing.com. This is the accepted version. 
removal occurs in sewer systems through aerobic heterotrophic conversion in gravity flow sewers and anaerobic metabolisms within thick biofilms attached on the wall or the benthic sediment in gravity flow sewer and pressure mains. Leakage of sewer systems is a worldwide issue even in developed countries such as in Denmark, Germany (Eiswirth and Hotzl, 2004; Dohmann 2017), UK (Ellis, 2001) and The Netherlands. Nowadays, much effort has been invested in China to improve aquatic environment quality, typically to eliminate 'black and odorous water bodies', and it was recognized that the issue is related to leakage from the sewer network (Zhang, 2017, ${ }^{1}$ Tang, 2017; Yang, 2017). Similarly, the interrelated relationships between 'black and odorous water bodies' and WWTP performance was recognized as saying 'black and odorous water bodies' will not disappear unless 'influent concentrations of WWTPs are increased' ('Tang, 2017).

Table 1 Characteristics of the influent of municipal WWTPs in China* and Singapore** (in $\mathrm{mg} / \mathrm{L}$ )

\begin{tabular}{|l|c|c|c|c|c|c|}
\hline & COD & BOD $_{5}$ & TSS & TN & $\mathrm{NH}_{4}-\mathrm{N}$ & TP \\
\hline China & 267 & 111 & 182 & 34 & 25 & 3.8 \\
\hline Shanghai & 280 & 138 & 158 & 32 & 24 & 4.1 \\
\hline Guangzhou & 181 & 92 & 186 & 24 & 19 & 3.5 \\
\hline Bingapore & 513 & 225 & 289 & 56 & 38 & 6.7 \\
\hline
\end{tabular}

${ }^{*}{ }^{2}$ CUWA, (2017), **Cao et al. (2014)

The quantification of leakage fractions of sewer network is an essential starting point for development of cost-effective approaches and rational strategies to solve the issue of leakage of sewer systems. However, this type of quantification is still limited. The objectives of this study were threefold: i. to develop a simple approach to quantify the fractions of sewer leakage including hydraulic flow, $\mathrm{C}, \mathrm{N}$ and $P$ mass loading and biological COD in-sewer removal; ii. to discuss the impact of sewer leakage on the 'black and odorous water bodies' and performance and operation of municipal WWTPs in China; and iii. to make recommendations according to the outcome of the study.

\section{METHODOLOGY AND APPROACHES}

Fig. 1 presents the concepts of leakage to/from the sewer and the mass balances based on calculations of fractions of sewer leakage. The $\mathrm{N}$ and $\mathrm{P}$ concentrations of the municipal WWTP influent are governed by: i. Person Loads (PLs) (Henze and Comeau, 2008) of (domestic) water consumption (L/cap.day), personal nitrogen and phosphorus discharge (g/cap.day), ii. In- and ex-filtration to/from sewer systems, assuming little reactions involving $\mathrm{N}$ and $\mathrm{P}$ (as conservative compounds), and only $\mathrm{P}$-free detergents are available; iii. little discharge of industry wastewater into sewers. For the COD concentration, biological in-sewer removal is another factor, in addition to the three factors mentioned above (Henze, et al.2002;). Given $75 \%$ of the populations in Singapore are Chinese, and the excellent construction quality and management practices of sewer systems in Singapore, the PLsr express personal (domestic) water consumption (PLrw), and discharged COD (PLrC), N (PLrn) and P (PLrp) in Singapore as reference in this

CIWA Publishing [2020]. The definitive peer-reviewed and edited version of this article is published in Water Science \& Technology, Volume 79, Issue 2, 334-341, 2019, doi: 10.2166/wst.2019.051 and is available at www.iwapublishing.com. This is the accepted version. 
study. The PLins express personal wastewater treated (PLinw), (L/cap.day), discharged COD (PLinc), N (PLinn) and P (PLinp) (g/cap.day) measured at the WWTP influent (Fig. 1). The PLinw of $0.196 \mathrm{~m}^{3} / \mathrm{cap}$.day in Singapore was calculated based on the total 1.5 mill cubic meter wastewater/day minus 400000 cubic meter industries wastewater/day and 5.61 million population (DSS, 2017) in Singapore. Given the separate sewer systems, $10 \%$ of hydraulic infiltration fraction during dry weather (DW), and negligible exfiltration assumed in Singapore, the PL of (domestic) water consumption (PLrw) in Singapore was $0.176 \mathrm{~m}^{3}$ /cap.day (Table 2). With the COD, $\mathrm{N}$ and $\mathrm{P}$ concentrations (Cs) of the municipal WWTPs influent (Table 1) (Cao, et al., 2014) and assuming 10\% biological COD in-sewer removal and negligible exfiltration of COD, N and P, the PLrs, which were calculated by the equation of (PLrw $x$ Cs) in Singapore, are: 121.0 g COD/cap.day (110 x 1.1) (PLrc), 9.7 g N/cap.day (PLrn) and 1.0 g P/cap.day (PLrp). These PLsr values are almost the same as in Austria and Germany (Krosis, 2015).

The leakage fractions of hydraulic flow, COD, N and P mass in the sewer systems of China (except Hong Kong, Macau and Taiwan), Shanghai, Guangzhou, and Beijing are evaluated in this paper. Considering the different development levels in different regions in China, 70\% of the PLs in Singapore was adopted as reference for China in this study, while $100 \%$ of the PLs in Singapore were used in calculations for Shanghai, Guangzhou, and Beijing. The personal(domestic) water consumption in China and three cities (Table 2) (PLw), were calculated from total water production minus water supplied to industry per capita, taken from ${ }^{2}$ CUWA (2017), and the personal wastewater (PLinw) were taken from ${ }^{1}$ CUWA (2017) (Table 2). The differences between the PLw and PLinw of the four cases show the (net) leakage, i.e. exfiltration, when the difference was positive; infiltration, when the difference was negative (Table 2). The influent concentrations (Cin) of WWTPs in China and three cities (Table 1) were the inflow hydraulic flow weighted averages of municipal WWTPs with the treatment capacity $\geqslant 100000 \mathrm{m3} /$ day (MHUR, 2017). The PLins were the personal loads and calculated by the equation of (PLinw $x$ Cin) of COD (PLinc, Table 2), N (PLinn) Table 3) and P (PLinp, Table 4) delivered to the WWTP's for the four cases. The differences between PLrs of COD, N and P in Singapore and respective PLins (PLsr - PLins) of the four cases indicate the magnitude of leakage of COD, $\mathrm{N}$ and $\mathrm{P}$ mass flow, respectively. The fractions of leakage were calculated by the equation of (PLrc - PLinc)/PLrc for COD (Table 2), (PLrn - PLinn)/PLrn for N (Table 3) and (PLrp - PLinp)/PLrp for P (Table 4) mass flow, respectively. As shown in the following sessions the exfiltration fractions of COD were always higher than those of $N$ and $P$. By assuming the same COD fraction of leakage as $\mathrm{N}$ and $\mathrm{P}$, the differences of $\mathrm{COD}$ fraction minus those of $\mathrm{N}$ or $\mathrm{P}$ (the exfiltration fraction of COD - the exfiltration fraction of $\mathrm{N}$ or $\mathrm{P}$ ) was regarded as the fraction of COD in-sewer removal through biological conversions. Depending on local conditions, the actual fraction of COD biological in-sewer removal could be higher than those calculated especially for sewer systems with high slope and high flow velocities as well in the case of nitrate rich groundwater infiltration. Thus, the fraction calculated in this study could be regarded as the minimum percentage. Given that the data used were annual average-based, the fractions calculated in this study are "net" values, and the different situations likely observed under dry and weather conditions were not assessed.

CIWA Publishing [2020]. The definitive peer-reviewed and edited version of this article is published in Water Science \& Technology, Volume 79, Issue 2, 334-341, 2019, doi: 10.2166/wst.2019.051 and is available at www.iwapublishing.com. This is the accepted version. 


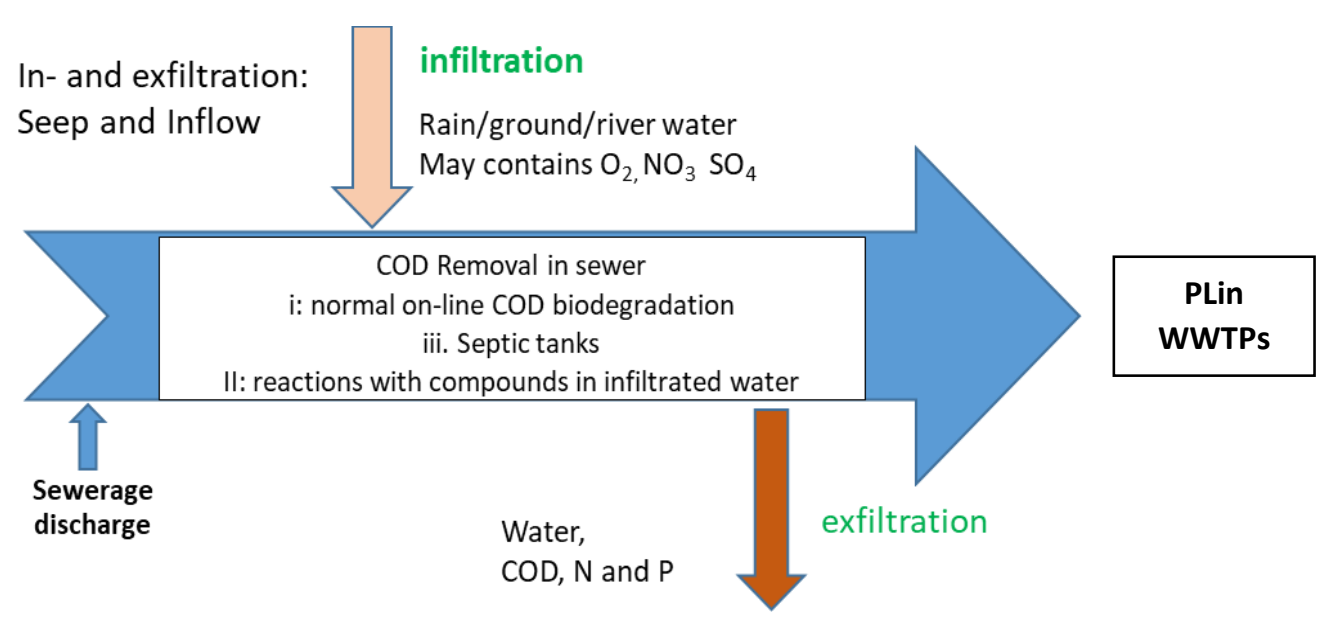

Fig. 1 Conceptualization of sewer in- and exfiltration

\section{RESULTS}

\section{Leakage fractions of the four cases}

\section{Case I China}

The average influent COD of $267 \mathrm{mg}$ COD/L for municipal WWTPs in China $2016\left({ }^{1} \mathrm{CUWA}, 2017\right)$ ranged between diluted and very diluted (Henze et al., 2002). As introduced in Methodology and Approach given the difference between the personal water consumption and personal water treated (Table 2), $39 \%$ of hydraulic flow (sewage) exfiltrated from the sewer system. Considering the results for major cities in Southern China presented below, hydraulic exfiltration may be occurring in Northern China, where the groundwater level is lower in general, compared to net infiltration in Southern China, where the groundwater level is higher in general. Infiltration in southern China may contribute to the low COD, $\mathrm{N}$ and $\mathrm{P}$ concentrations (Table 1 ) due to dilution. In contrast, for Norther China, given the difference between the PL of COD $85 \mathrm{~g}$ COD/cap.day (121 x 70\%) (reference, PLrc) and PLin of $28 \mathrm{~g}$ COD/cap.day (PLrc) (Table 2,) 66\% of the COD in municipal sewage discharged exfiltrated out of the sewer systems including consumed by biological in-sewer reaction (Table 3). Using the similar approaches as for COD, $48 \%$ of $\mathrm{N}$ (Table 3 ) and $44 \%$ of $\mathrm{P}$ (Table 4 ) exfiltrated from sewer systems. Compared to that of COD, the smaller fractions of $\mathrm{N}$ and $\mathrm{P}$ ex-filtration point to the biological COD in-sewer removal. Taking $46 \%$ as the average fraction of direct exfiltration then, at least $20 \%$ COD $(66 \%-46 \%)$ was removed through biological in-sewer conversions (Fig. 2).

CIWA Publishing [2020]. The definitive peer-reviewed and edited version of this article is published in Water Science \& Technology, Volume 79, Issue 2, 334-341, 2019, doi: 10.2166/wst.2019.051 and is available at www.iwapublishing.com. This is the accepted version. 
Table 2 The Person Loads of water consumtion, treated and fractions of hydraulic leakage and COD exfiltration

\begin{tabular}{|l|c|c|c|c|c|c|}
\hline & $\begin{array}{c}\text { PL of water } \\
\text { consumption } \\
\text { (PLw)* } \\
\text { m3/cap.d }\end{array}$ & $\begin{array}{c}\text { PLin of water } \\
\text { treated } \\
\text { (PLinw)** } \\
\text { m3/cap.d }\end{array}$ & $\begin{array}{c}\text { Per. PL of water } \\
\text { in- or ex- } \\
\text { filtrated } \\
\% * * *\end{array}$ & $\begin{array}{c}\text { PLin of COD in } \\
\text { inf. WWTPs } \\
\text { (PLinc) } \\
\text { g COD /cap.d }\end{array}$ & $\begin{array}{c}\text { PL of COD } \\
\text { disappeared }\end{array}$ & $\begin{array}{c}\text { Fraction of COD } \\
\text { exfiltration, }\end{array}$ \\
\%**** \\
\hline China & 0.168 & 0.103 & +39 & 28 & 56 & 66 \\
\hline Shanghai & 0.223 & 0.252 & -13 & 71 & 50 & 41 \\
\hline Guangzhou & 0.246 & 0.277 & -13 & 50 & 71 & 59 \\
\hline Beijing & NA & 0.194 & NA & 100 & 21 & 17 \\
\hline Singapore & 0.176 & 0.196 & -10 & 110 & 11 & 10 \\
\hline
\end{tabular}

* ${ }^{2}$ CUWA, (2017), ${ }^{* * 1}$ CUWA, (2017), calculated by (PLw-PLinw)/PLw, **** Calculated by (PLrc-PLinc)/PLrc, "Cao et al. (2014).

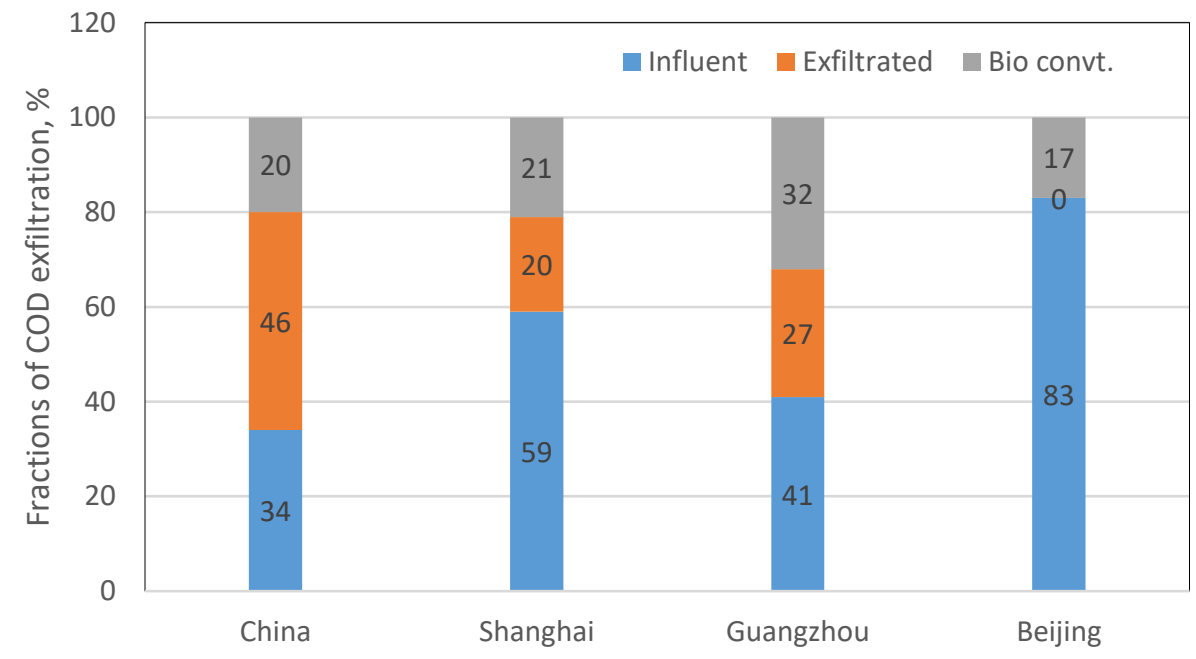

Fig. 2 COD fate in the sewer systems of China, Shanghai, Guangzhou, and Beijing

Table 3 The nitrogen Person Loadat the WWTP influent (PLinn) and the fractions of exfiltration

\begin{tabular}{|l|c|c|c|}
\hline & $\begin{array}{c}\text { PLin of N in inf. } \\
\text { WWTPs (PLinn), } \\
\text { g N/cap }\end{array}$ & $\begin{array}{c}\text { PL of N } \\
\text { disappeared } \\
\text { g N /cap.d }\end{array}$ & $\begin{array}{c}\text { Fraction of N } \\
\text { exfiltration, } \\
\% *\end{array}$ \\
\hline China & 3.5 & 3.3 & 48 \\
\hline Shanghai & 8.0 & 1.7 & 18 \\
\hline Guangzhou & 6.6 & 3.1 & 32 \\
\hline Beijing & 10 & $(+0.03)$ & NA \\
\hline Singapore & 9.8 & 0.2 & 0 \\
\hline
\end{tabular}

* Calculated by (PLrn - PLinn)/PLrn

CIWA Publishing [2020]. The definitive peer-reviewed and edited version of this article is published in Water Science \& Technology, Volume 79, Issue 2, 334-341, 2019, doi: 10.2166/wst.2019.051 and is available at www.iwapublishing.com. This is the accepted version. 
Table 4 The phosphorus Person Loads at the WWTPs influent (PLinp) and the fractions of exfiltration

\begin{tabular}{|c|c|c|c|}
\hline & $\begin{array}{c}\text { PLin of P in inf. } \\
\text { WWTPs (PLinp), } \\
\text { g P /cap.d }\end{array}$ & $\begin{array}{c}\text { PL of P } \\
\text { disappeared } \\
\text { g P /cap.d }\end{array}$ & $\begin{array}{c}\text { Fraction of P } \\
\text { exfiltration, } \\
\% *\end{array}$ \\
\hline China & 0.4 & 0.4 & 44 \\
\hline Shanghai & 1.0 & 0.3 & 23 \\
\hline Guangzhou & 1.0 & 0.3 & 23 \\
\hline Beijing & 1.3 & NA & 0 \\
\hline Singapore & 1.3 & 0.2 & 0 \\
\hline
\end{tabular}

*Calculated by (PLrp - PLinp)/PLrp

\section{Case II Shanghai}

The flow weighted average influent COD concentration in Shanghai, which were calculated from the eleven municipal WWTPs with capacity $\geqslant 100000 \mathrm{~m}^{3} /$ day (MHUR, 2017), was $280 \mathrm{mg} \mathrm{COD/L}$ (Table 1). It ranged between diluted and very diluted according to Henze et al. (2002). Differing from hydraulic exfiltration in China, $13.4 \%$ (net) of hydraulic infiltration occurred according to the PLw of water consumption and PLinw of water treated (Table 2). This may be attributed to the high groundwater level in the Yangtze delta. The high level operation of the sewer networks, illegal connection with rain water system (Zhang, 2017; ${ }^{1}$ Tang, 2017), fluctuation of groundwater levels (Eiswirth and Hotzl, 2004) etc. might be relevant factors to the moderate fractions. $41 \%$ of COD (Table 2), $18 \%$ of $N$ (Table 3 ) and $23 \%$ of $\mathrm{P}$ (Table 4) are on average lost from the sewer system. Taking $20 \%$ as the average direct exfiltration fraction, the fraction of biological COD in-sewer conversion was estimated as $21 \%$ COD (Fig. 2).

\section{Case III Guangzhou}

The hydraulic flow weighted average influent COD concentration of $181 \mathrm{mg}$ COD/L (Table 1) was calculated from the nineteen municipal sewage WWTPs with capacity $\geq 100000 \mathrm{~m}^{3} /$ day in Guangzhou (MHUR, 2017). The concentrations were generally very diluted (Henze, et al., 2002). Of the influencing factors, high water consumption (269 L/cap.day) was a contributor. The fraction of hydraulic infiltration was $13 \%$ (Table 2) . The fractions of COD, N and P exfiltration were 59\% (Table 2), 32\% (Table 3) and 23\% (Table 4), respectively. Assuming $27 \%$ as the direct exfiltration fraction, $32 \%$ of COD was removed through biological in-sewer conversion (Fig. 2), which is higher than China and Shanghai.

\section{Case IV Beijing}

The average influent concentration for COD was $513 \mathrm{mg} / \mathrm{L}$ (Table 1), which was calculated from the eleven municipal WWTPs with capacity $\geqslant 100000 \mathrm{~m}^{3} /$ day in Beijing (MHUR, 2017). It was much higher than China average, Shanghai and Guangzhou. The hydraulic in- and exfiltration fraction could not be calculated because of a lack of personal water consumption data, although the groundwater level is deeper for sewer systems in Beijing (Gan, 2017). However, only 17\% of COD (Table 2) was estimated

CIWA Publishing [2020]. The definitive peer-reviewed and edited version of this article is published in Water Science \& Technology, Volume 79, Issue 2, 334-341, 2019, doi: 10.2166/wst.2019.051 and is available at www.iwapublishing.com. This is the accepted version. 
to be removed through biological in-sewer conversion (Fig. 2), and little $\mathrm{N}$ and $\mathrm{P}$ were ex-filtrated (Tables 3 , and 4), demonstrating an excellent condition of the sewer systems in Beijing.

\section{High inert solid component and low $\mathrm{BOD}_{5} / \mathrm{N}$ ratio}

Data reported by others can be used to assess the inert solids fractions for Chinese sewage. The fraction of inert particulate COD (Xi) measured for the influent of WWTPs in Shanghai could be above $30 \%$ (Zhou et al., 2008), and even higher values were measured in other city's sewage (Wu, 2018), compared to between $8 \%$ and $20 \%$ for typical municipal sewage (Henze, 1991). The particulate $\mathrm{XBOD}_{5} / \mathrm{SS}$ ratio of the influent in many WWTPs in China ranged between 0.3 and 0.5 (Dai, 2017), which is much lower than the range between 0.8 and 1.0 for typical sewage (Henze et al., 2002). Similarly, the XCOD/SS ratio of the influent measured in some WWTPs in China was often < 1.0 (Wu, 2018; Yang, 2018), which was below the typical range between 1.2 and 2.0 (Henze, et al., 2002) (1.4 in Singapore, Cao et al., 2014). The VSS/SS ratio of the influent in dozens of municipal WWTPs varied between $30 \%$ and $60 \%$ (Dai, 2017; Zheng, 2017; Ji, 2017; Wu, 2018), which was much lower than the $70 \%$ for typical municipal sewage (Henze et al., 2002). All these data demonstrate the high inert particulate COD (Xi) and inorganic solids in the sewage in many locations in China.

The $\mathrm{BOD}_{5} / \mathrm{N}$ ratios of the municipal sewage in China and three cities ranged between 3.3 (China) and 4.4 (Shanghai) (Table 5) and averaged 3.9, which is at the low range (3 - 4) (Henze et al., 2002). The influent $\mathrm{COD} / \mathrm{N}$ ratio of four cases ranged between 7.5 (Guangzhou) and 8.8 (Beijing) (Table 5) and averaged 8.0, which is the upper value of the low range (6 - 8) (Henze et al., 2002) (Table 5). Both ratios were much lower than in Singapore (Table 5). These abnormal ratios for the sewage in many WWTP influents are closely related to leakage of the sewer works, as discussed in following sections.

Table 5 The ratios of organic carbon and nitrogen of the sewages of China, three cities* and Singapore**

\begin{tabular}{|l|c|c|c|c|c|}
\hline Ratio & China & Shanghai & Guangzhou & Beijing & Singapore \\
\hline COD/BOD5 & 2.4 & 2.0 & 2.0 & 2.3 & 1.8 \\
\hline COD/TN & 7.7 & 8.7 & 7.5 & 8.8 & 11.3 \\
\hline BOD5/TN & 3.3 & 4.4 & 3.8 & 4.0 & 7.6 \\
\hline N/P & 8.9 & 7.8 & 6.8 & 8.5 & 7.7 \\
\hline
\end{tabular}

* ${ }^{2}$ CAWU (2017), ** Cao et al. (2014).

\section{DISCUSSIONS}

\section{Sewer leakage and interactions with the aquatic environment}

The leakage of sewer works in China is startling: approx. 40\% of sewage and half of COD, $N$ and $P$ in the sewers are exfiltrated out the sewer system without any treatment. This means that only approx. half of municipal sewage reaches the treatment plants and to be treated, at the same time another $50 \%$ of sewage is discharged into the aquatic environment. The fractions of COD, $\mathrm{N}$ and $\mathrm{P}$ ex-filtrated from the sewers in Shanghai and Guangzhou are approx. 30\%. However, the fractions of exfiltration in these two cities could be higher than $30 \%$ if all the WWTPs with capacity less than $100000 \mathrm{~m}^{3} /$ day in these two

CIWA Publishing [2020]. The definitive peer-reviewed and edited version of this article is published in Water Science \& Technology, Volume 79, Issue 2, 334-341, 2019, doi: 10.2166/wst.2019.051 and is available at www.iwapublishing.com. This is the accepted version. 
cities are included in the calculations. The COD, N and P ex-filtrated from sewer systems recharge groundwater or surface water and contribute to 'black and odorous water bodies'. Notably, exfiltration of these compounds results in diffuse pollution, which is difficult to control (Metcalf and Eddy, 2004). The ex-filtrated sulphate and nitrogen compounds contained in the sewage can be either reduced (sulphate to sulfite) or oxidized (ammonia to nitrate/nitrite,) depending on environment conditions. These reduced or oxidized compounds then can infiltrate again into the damaged sewer systems to react with oxygen or organics of sewage (Eiswirth and Hotzl, 2004; Huisman et al., 2004). Also, infiltrated ground or river water may bring reactive compounds such as nitrate $\left(\mathrm{NO}_{3}\right)$, sulfate $\left(\mathrm{SO}_{4}\right)$ and dissolved oxygen etc. into the sewer (Eiswirth and Hotzl 2004) allowing biological in-sewer reactions that consume organic compounds, resulting in consumption of biodegradable COD.

The average N/P ratio of influents to WWTPs in China, Shanghai, Guangzhou and Beijing was approx. 8.0, which is close to 7.7 in Singapore (Table 5). The observation that N/P ratios are in a similar range supports the assumption of $\mathrm{N}$ and $\mathrm{P}$ as conservative compounds in sewer processes. Given the average $55 \%$ of COD exfiltration, and the $22 \%$ of $\mathrm{N}$ and $\mathrm{P}$ exfiltrated, the fraction of COD in-sewer removal was at least $23 \%$. Biological COD in sewer removal could be through aerobic heterotrophic conversion or anaerobic metabolisms (Henze, 1992; Sollfrank and Gujer, 1991), and/or reduction by denitrification of nitrate (Abdul-Talib et al., 2002), which could be the same percentage ( $20 \%$ ) as aerobic heterotrophic conversion (Nielsen et al., 1992; Huisman et al., 2004). For the latter, high nitrate concentrations in the contaminated groundwater nationwide distributed in China was reported (Gu et al., 2013; Han et al., 2016), although few studies on nitrate reaction with COD in sewer systems have been published.

Rationally designed and operated sewer systems are essential to protect the aquatic environment, eliminate 'black and odorous water bodies' and allow the efficient and sustainable operation of municipal WWTPs. The Beijing case demonstrates the effectiveness of the management strategy of "intergrading the plants and sewer system at a whole" (Yang, 2017), where all large municipal WWTPs remove nutrients and operate anaerobic digesters to produce biogas for energy recovery. With the recently promulgated technology guideline for sewer rehabilitation (MHUR, 2016), which should result in a rational and workable plan for the implementation of a sewer rehabilitation strategy, the sewer system can be improved and operated at high efficiency in China.

\section{Impact on the Performance and Operation of WWTPS}

Hydraulic infiltration (Shanghai and Guangzhou) and exfiltration (China) can result in the operation of the hydraulic flow-based treatment system units (such as screen, grit removal, pumps and pipes, etc.) to deviate from their design capacity. The high exfiltration fractions of COD, $N$ and $P$ result in the biological units operating under low mass loading conditions. The low ratios of influent XCOD/SS and VSS/TSS are related to infiltrated fine sand and clay with a dimeter $<200 \mu \mathrm{m}$ derived from land development and urbanization (Ji, 2017). The high fractions of COD exfiltration and biological in sewer removal directly cause the lower $\mathrm{C} / \mathrm{N}$ (and $\mathrm{BOD} / \mathrm{N}$ ) ratio of municipal sewage and addition of external carbon for nutrient removal in many WWTPs in China. Furthermore, given the abnormal high fraction of inert (Xi) and low XCOD/SS ratio, the efficiencies of denitrification and biological phosphorus removal in the context of WWTPs in many WWTPs in China could be reduced, compared to those of typical

CIWA Publishing [2020]. The definitive peer-reviewed and edited version of this article is published in Water Science \& Technology, Volume 79, Issue 2, 334-341, 2019, doi: 10.2166/wst.2019.051 and is available at www.iwapublishing.com. This is the accepted version. 
sewage under the similar influent COD/N ratio (Puig, et al., 2010). Calculations show, corresponding to the average influent COD of $340 \mathrm{mg} / \mathrm{L}$ for the four cases (Table 1), a reduction of $15 \%$ of the COD exfiltration could increase approx. $50 \mathrm{mg}$ biodegradable $\mathrm{COD} / \mathrm{L}$ in the influent, which would enable an extra approx. $10 \mathrm{mg} \mathrm{NO}-\mathrm{N} / \mathrm{L}$ to be denitrified.

The fine inorganic solids escape grit removal and accumulate in activated sludge tanks, thereby reducing the VSS/MLSS ratio of the mixed liquor to the range between $30 \%$ and $50 \%$ in many WWTPs (Zhong, 2017; Ji, 2017; Li, 2018) compared to the normal range between $70 \%$ and $80 \%$ (Henze et al., 2002). The reduced VSS/TSS ratio requires extra volume (space) of activated sludge tank and anaerobic digesters (Daigger, 2014). Furthermore, the inert solids that settle in the reactor can reduce effective reactor volume $(\mathrm{Ji}, 2017)$. The result can be an inability for effluent quality to meet the discharge requirements (Zheng, 2017). The high inert inorganic and COD content of the sludge fed to anaerobic digesters (Ji, 2017) leads to lower biogas yield, corresponding to low removal efficiency of solids (Dai, 2017).

The high inorganic solid content of sludges (primary and waste activated) not only decrease biogas production in digestion, and also heat value content of dewatering sludge, making auto-thermal incineration operation difficult (Ji, 2017). Erosion of mechanical equipment e.g., pumps, pipes, and blowers etc. due to fine sand and clay were observed (Ji, 2017). Together with the impacts discussed above, all of these items reduce the efficiency and sustainable WWTP operation, demonstrating the deteriorated impact of sewer leakage on the performance and operation of individual units and the WWTPs as a whole. On the other hand current practices of removal of primary settling tanks and anaerobic sludge digesters could be over-simplified. Much careful considerations and evaluations to tailor the facility and process to the specific local sewage characteristics may be needed in order to achieve optimal design and upgrading of municipal WWTPs. In response to the unique sewage characteristics in China a rational, integrated design guideline for individual units/processes, and whole WWTP process, in China is necessary and should be developed (Cao and Daigger, 2018).

\section{SUMMARY AND RECOMMENDATIONS}

The leakage of sewers in Case China is startling: approximately $40 \%$ of sewage and half of COD, N and P in the sewers are exfiltrated or removed in the sewer system without any treatment, which illustrates that only approximately half of municipal sewage reaches the treatment plants to be treated. The substantial exfiltration of sewage and chemicals without treatment impairs the aquatic environment, contributes to 'black and odorous water bodies', and wastes water, energy and nutrients.

The high fractions of COD exfiltration and biological in-sewer removal are resulting in the low COD concentration and $\mathrm{C} / \mathrm{N}$ ratio and biodegradable COD components of WWTP influents. As a consequence, a series of problems occurs, such as extra bioreactor volumes required, high cost of nutrient removal, low biogas yield and sludge mineralization rate, poor energy recovery, and mechanic erosion. Combined with the negative impact on the aquatic environment, restoration of the integrity of sewer systems to

CIWA Publishing [2020]. The definitive peer-reviewed and edited version of this article is published in Water Science \& Technology, Volume 79, Issue 2, 334-341, 2019, doi: 10.2166/wst.2019.051 and is available at www.iwapublishing.com. This is the accepted version. 
eliminate in- and exfiltration would be a pressing challenge to close the urban water cycle and achieve integrated and sustainable resource management.

Recommendations for further actions are provided as following:

To enhance the investigations on the leakage (in- and exfiltration) of current sewer systems

- Carry out a national survey on in- and exfiltration in the current sewer network aimed at rational estimation and calculation of the fractions of in- and exfiltration of hydraulic flow, COD, N and P, and biological COD in-sewer removal at the levels of municipalities and the corresponding WWTPs. To obtain quantitative results, investigations should include those under dry/wet-weather and temporal/spatial conditions (e.g. groundwater level changes during the year) to facilitate exploration of the complex mechanisms behind the phenomena.

- Investigate the influences of in- and exfiltration on the aquatic environment, especially 'black and odorous water bodies', in the context of the local conditions;

- Investigate the interactions between infiltrated groundwater/river water and sewage and between exfiltrated sewage and ground/river water, and the effects of these interrelations on the aquatic environment and biological COD in-sewer removal;

- Establish a tasks list and alternatives, priorities them and then formulate a plan of rehabilitation and management of damaged sewers, according to a cost-effective analysis.

To enhance studies on the performance and operation of municipal WWTPs under current sewage characteristics

- Evaluate sewage characteristics, especially the fractions of biodegradable and inert particulates, under local conditions, since knowledge of these characteristics is an indispensable step for the reliable design and operation of wastewater treatment processes and WWTP as a whole;

- Assess the efficiency of individual units/processes, typically grit removal installations and biological units, under current influent characteristics and benchmark with those under typical influent conditions with normal exfiltration and infiltration. Then identify the bottlenecks for improvement or upgrading accordingly;

- Develop rational, integrated design guidelines for individual units/processes for the WWTP as a whole under the current sewage characteristic conditions, especially for areas where in- and exfiltration of sewer works is serious.

\section{LITERATURE}

Abdul-Talib S., Hvitved-Jacobsen T., Vollertsen J. and Ujang Z. (2002) Anoxic transformations of wastewater organic matter in sewers - process kinetics, model concept and wastewater treatment potential, Wat. Sci. and Technol. 45(3): 53-60

Cao, Y. S., Kwok, B. H., Noraini, A. Z. Lau, C.L., Zulkifli, I., Chua, S.C., Wah, Y. L. and Yahya A. G. (2014) The Mainstream Partial Nitritation-Anammox Nitrogen Removal in the Largest Activated Sludge Process and Comparisons with Other BNR Activated Sludge Process in Singapore, IWA World Water Congress, 21-26 Sept. 2014, Lisbon.

Cao Yeshi and Daigger Glen (2018) Key influences of sewage characteristics to the design and upgrading of WWTPs: from empirical to mechanistic. $2^{\text {nd }}$ National workshop on WWTPs upgrading to meet new discharge standard. 3 - 5 Sept. 2018. HuFai.

CIWA Publishing [2020]. The definitive peer-reviewed and edited version of this article is published in Water Science \& Technology, Volume 79, Issue 2, 334-341, 2019, doi: 10.2166/wst.2019.051 and is available at www.iwapublishing.com. This is the accepted version. 
${ }^{1}$ CUWA (2017) Wastewater statistic Annual Book 2017.

${ }^{2}$ CUWA, (2017) Water supply statistic Annual Book 2017.

Dai S.H. (2017) Bottleneck and technology Analysis of Sludge treatment and disposal. The $8^{\text {th }}$ national workshop of municipal sludge treatment and disposal. Beijing, 25 May 2017.

Daigger G. T. (2014) Ardern and Lockett Remembrance IWA Conference: Activated Sludge - 100 Years and Counting Essen, Germany 12 June, 2014.

Dohmann M. (2017) Control and treatment of black and odorous waterbodies: control of rainwater and pollution overflow, workshop of Control and treatment of black and odorous waterbodies. 4-5 May 2017, Shanghai.

DSS (2017) Latest Data, http://www.singstat.gov.sg/statistics/latest-data\#16

Eiswirth and Hotzl (2004) Impact of leaking sewers on urban groundwater. In: Chilton, J. et al. (ed.). Urban Environment. 399-404Ellis J.B. (2001) Sewer infiltration/exfiltration and interactions with sewer flows and groundwater quality, INTERURBA II, LISBON, PORTUGAL, 19-22 February 2001.

Gu B., Ying G., Chang S.X., Luo W.D., Chang J. (2013) Nitrate in groundwater of China: Sources and driving forces. Global Environmental Change, 23: 1112-1121.

Gan Y.P. (2017) Personal communications on in- and exfiltration of sewer systems in China

Han D.M., Currel M.J. and Cao G.L. (2016) Deep challenges of China's war on water pollution. Environmental Pollution 218:1222-1233

Henze M. (1992) CHARACTERIZATION OF WASTEWATER FOR MODELLING OF ACTIVATED SLUDGE PROCESSES, Wat. Sci. Tech. 25(6):1-15.

Henze M., Harremoës P., la Cour Jansen J. and Arvin E. (2002) Wastewater Treatment: Biological and Chemical Processes, 3rd ed, Springer-Verlag, Berlin.

Henze H. and Comeau Y. (2008) Wastewater Characterization. In: Henze et al. (ed.) Biological Wastewater Treatment: principles, modelling and design, IWA Publishing, London, 2008.

Huisman JL, Gasser T, Gienal C, Kühni M, Krebs P, Gujer W. (2004) Quantification of oxygen fluxes in a long gravity sewer. Water Res. 38(5): 1237-47.

Ji F. Y. (2017) The influences of fine sand to resource recovery of sludge and technology for sand removal. Annual meeting of J. water and wastewater, 21 Oct 2017, Xiamen.

Krosis H. (2015) Energy Efficiency in Waste Water Treatment: assessment methodology and practical consequences, NUS, Singapore, March 26, 2012

Li J. (2018) Personal communication on mixed liquor in activated sludge tanks.

Metcalf and Eddy (2003) Wastewater Engineering Treatment and Reuse. 4th Edition, McGraw Hill.

MHUR (2016) Technology guidelines to solve black and odorous urban river water.

MHUR (2017) Information system of China municipal wastewater treatment.

Nielsen P.H., Raunkjær K., Norsker N.H., Jensen N. A., Hvitved-Jacobsen T. (1992) Transformation of Wastewater in Sewer Systems - A Review, Wat. Sci. and Technol., 25 (6): 17-31

Puig S., van Loosdrecht MCM., Flameling AG., Colprim J., Meijer SCF. (2010) The effect of primary sedimentation on full-scale WWTP nutrient removal performance. Wat. Res 44: 3375 - 3384

Sollfrank U., and Gujer W. (1991) Characterization of Domestic Wastewater for Mathematical Modelling of the Activated Sludge Process, Wat Sci. and Technol. 23 (4-6): 1057-1066.

${ }^{1}$ Tang J.G. (2017) River water quality: First solve sewer filtration. Urban water. 13 June, 20 June 2017

${ }^{2}$ Tang J. G. (2017) Technology guidelines to solve black and odorous urban river water

CIWA Publishing [2020]. The definitive peer-reviewed and edited version of this article is published in Water Science \& Technology, Volume 79, Issue 2, 334-341, 2019, doi: 10.2166/wst.2019.051 and is available at www.iwapublishing.com. This is the accepted version. 
Wu Y. Y. (2018) Personal communication on characteristics of raw sewage for modeling.

Yang A. M. (2018) Personal communications on Characteristics of raw sewage for modeling.

Yang X.P. (2017) Personal communications on in- and exfiltration of sewer systems in China.

Zhang Y. (2017) Urban black and odorous water bodies: actions with clear goals

Zhang Y. (2018) Personal communication on low C/N ratio.

Zhou Z., Wu Z.C., Wang Z.W., Tang S.J., Gu G.W. (2008) COD fractionation and parameter estimation for combined sewers by respirometric tests, Chemical technology and biotechnology. 83:1596-1601. https:// doi.org/ 10.1002/jctb.1984

Zheng X. Z. (2017) Technology analysis and influencing factors analysis of municipal sludge volume reduction. The 8th national workshop of municipal sludge treatment and disposal. Beijing, 25 May 2017

Zheng X. Z., (2018) Personal communications on infiltration of sewer system in Tianjin.

CIWA Publishing [2020]. The definitive peer-reviewed and edited version of this article is published in Water Science \& Technology, Volume 79, Issue 2, 334-341, 2019, doi: 10.2166/wst.2019.051 and is available at www.iwapublishing.com. This is the accepted version. 